\section{Working Men's Colleges}

I HAVE only just seen your remarks on Working Men's Colleges, and your siggestion that "men and women should be treated, not as artizans, mechanics, or gentlemen, but simply as men and women." May I, speaking as a member of the College in Creat Ormond Street, and also of the younger college here, and having an intimate knowledge of both cluring the whole of their existences, assure you that both these colleges were opened and have been carried on in the spirit you suggest, and in no other? Certainly, we have never in either college desired to treat zuomen as either "artizans, mechanics, or gentlemen."

Secondly, I do not think either college is second, even to the "Berlin Working Men's Club," in catholicity. Each college puts forth a programme of what it can give its members, and there. is not in either college the slightest effort to induce any mem. ber to do anything but what he has a spontaneous desire to do. Neither college "belongs to any religious or anti-religious body." Neither college has any "Shibboleth of any kind whatever."

Thirdly, your suggestion that all the colleges and clubs should be united into one, would have more value in a small town than in London, with its hundreds of miles of streets and its millions of inhabitants.

Lastly, there is an essential difference between a college and a club. The one has a foundation in work, the other in recreation; the chief work of the one is mental, of the other social; in both it is moral. Both are necessary, but they need not necessarily be carried on in the same building.

Another point is that working men cannot form a college for and $b y$ themselves, except they scarcely need it. The number of members needful to defray the expenses is so large, and the number of men in London possessing the elementary education requisite to give them an intelligent and persistent desire for such a place is comparatively so small, that I do not think any college in London can be wholly self-supporting for some years to come.

If any of your readers desire to know what kind of work the two colleges are doing, I shall be happy to give them full particulars of the work and of its difficulties, and still more of its need to be done. I think you are in error in speaking of the extension of the scientific programme of Great Ormond Street College. I have before me the new programme of that college.

In this, the younger college, we have put before our students a larger number of science classes than we have hitherto done, because we are beginuing to find that the men who have passed through our night schools and elementary classes give us hopes of doing good in this way. Possibly it is to this that you meant to refer.

October 4

W. ROSSI'TER, Hon. Sec.

TWe wrote by the card in speaking of a projected extension of the scientific instruction at the Working Men's College in Great Ormond Street. - ED.]

\section{Lunar Rainbow}

I HAVE just witnessed this evening (Monday, 10th, 7.30 P.M.) a magnificent lunar rainbow, distinctly coloured throughout, and with the refiection bright towards the west. The space within the bow appeared lit up by a silvery haze, offering a marked contrast to the inky appearance of the cloud beyond the bow.

The moon was shining brightly as the shower commenced during which the rainbow was seen. It was observed at dif. ferent times during the evening by several persons.

Cromer, Norfolk

J. G. Duthie

\section{NOTES}

We have great pleasure in announcing that the American Government have voted $6,000 \%$. for the expedition which will be sent to Spain and Sicily to observe the coming eclipse. It will be in the recollection of our readers that our own Government have refused to give either a single ship or a single shilling in aid of our own observations; as we said before, comment is useless.

We have also a word to add to another instance of American enlightenment which we chronicled last week, namely, the vote of 50,000 dollars towards the construction of a refractor similar to that recently erected by Mr. R. S. Newall at Gateshead. The Superintendent of the U.S. Naval Observatory, Washington, has written to Mr. Newall a letter which we have been permitted to see, ir which, after referring to the munificence which has endowed astronomy with such an instrument as the Newall telescope, he requests permission for Prof. Newcombe to inspect it, with a view of judging what devices and mechanical arrangements are best adapted to secure the successful and easy manipulation of the American instrument.

THE death of Prof. Miller has been followed by another heavy loss to Chemical Science in that of Dr. Augustus Matthiessen, one of the rising chemists of greatest promise in this country. The work which he had already done had acquired for him a reputation equalled by few, and exceeded by none of his fellow-workers of his own age; to this we hope to refer more at length next week. He occupied the position of Lecturer on Chemistry at St. Bartholomew's Hospital, and was, at the time of his death, one of the Examiners to the University of London. He was in his 39 th year.

THE "fish torpedo * which, as we stated some little time agn, has been for some time subjected to various experimental trials by a committee of naval officers, under Captain Arthur, R.N., was put to a practical proof on Saturday, at Shecrness. The Oberon, paddle-wheel steamer, had been specially supplied with a 12-horse power engine and air pumps for filling the torpedo with compressed air, and fitted with a large discharging tube at the bow for launching it under water. The peculiarity of the torpedo is that it will maintain its passage at any particular depth between five and fifteen feet from the surface; the propulsion being entirely submarine and effected at the rate of six or seven miles an hour by the action of the compressed air on a screw propeller. Two torpedoes were run against the Aigle, a large hulk lying in the harbour, both from a distance of 140 yards. The first contained a charge of $67 \mathrm{lb}$. of gun-cotton, and lit the hulk, exploding on impact, and making a clean hole, 20 feet by Io feet in area, and sinking her at once. Nets were placed at $I_{\mathfrak{y}}$ feet from the side of the hulk, and the second torpedo min at them, being launched from a framework attached beneath a boat. This torpedo, containing a clarge of $18 \mathrm{lb}$. glyoxiline, was caught in the nets and expinded there, doing no damage whatever to the side of the bulk. The machine is the invention of Mr. Whitehead, an English engineer, having works at Fiume, in Hungary.

We must refer our readers to the October number of the Astronomical Register for an account of a discussion on the great Melboume telescope, at the Royal Society of Victoria. The colonists mistrust their great reflector, and we do not wonder at it, the day for metallic specula is past, and we regret that our Royal Society had anything to do with sending out such an instrument.

THE Astronomical Register announces that the post of Government Astronomer at Sydney is vacant by the death of $\mathrm{Mr}$. George K. Smalley.

Now that the Government are accused by a tribunal appointed by themselves, of having built a top-heavy ship " in deference to public opinion, as expressed in Parliament and in other channels" (sic) and "in opposition to the views and opinions" of their scientific adviser, might we be allowed to suggest that the more Government attempts to encourage the advancement of scientific ideas and studies among members of Parliament and other channels, the better? The cost of the Captain in hard cash would have helped to disseminate a vast amount of scientific education and interest througlout the land had it been properly spent ; and now it is quite lost, because the Government: are Philistincs, and do not like Science, and build top-heavy ships because ignorant members of Parliament and other "shan. nels" clamour for them, 